IFN Working Paper No. 808, 2009

Perspectives on the Success and Early History of the Industrial Institute for Economic and Social Research

Magnus Henrekson 


\title{
Perspectives on the Success and Early History of the Industrial Institute for Economic and Social Research
} (IUI) ${ }^{*}$

\author{
Magnus Henrekson ${ }^{\#}$
}

March 3, 2011

\begin{abstract}
The Industrial Institute for Economic and Social Research (IUI) was founded in 1939. In less than ten years, IUI grew from a small survey bureau to a leading research institute focused on microeconomic research relevant to industrial development. Based on a number of new commemorative essays and biographies written by or about former IUI researchers published in Henrekson (2009), this essay describes the Institute's accomplishments and the particular research environment at IUI. It also discusses the conditions conducive to a creative, productive research environment. While most of these accounts do not extend beyond the end of the 1970s, the insights provided are highly relevant for contemporary research institutes.
\end{abstract}

JEL Codes: B31; D02; D21; L20; O14

Keywords: Applied research; Creativity; Entrepreneurship; Research institute.

\footnotetext{
* A special thanks to Göran Albinsson Bruhner, Robin Douhan, Henrik Horn, Dan Johansson, Lars Jonung, Henrik Jordahl, Lars Persson, Mats Persson, Bo Sandelin and Birgitta Swedenborg for their valuable comments on earlier versions of this essay, and to Linda Nyberg for the translation from the first draft in Swedish.

\# Magnus Henrekson has been the CEO of the Research Institute of Industrial Economics (IFN) since November 2005 and was the Jacob Wallenberg Professor of Economics at the Stockholm School of Economics until 2009. In recent years, his own research has primarily focused on the economics of entrepreneurship.

Contact details: Research Institute of Industrial Economics (IFN), Box 55665, SE-102 15

Stockholm. Tel.: 08-665 45 02. E-mail: Magnus.Henrekson@ifn.se. Personal website: www.ifn.se/mh.
} 
Seventy years have passed since the Industrial Institute for Economic and Social Research (Industriens Utredningsinstitut, IUI) was founded. Despite considerable skepticism and resistance from leading circles of the business world, 1939 saw the realization of legendary ASEA president Sigfrid Edström's conviction that Swedish enterprise needed its own qualified research institute. IUI_renamed IFN in $2006^{1}$ — has been a leading institution in applied research in Sweden, and has also figured prominently in economic policy debate since its inception.

In celebration of the Institute's 70th anniversary, more than 30 former IUI researchers were invited to reflect upon the impact their time at IUI had on their personal and professional development. These contributions, together with several essays about former IUI CEOs and chairmen, have been compiled in Henrekson (2009).

This essay uses this material to explore two questions. First, what made the research environment at IUI so special? Second, which conditions create and maintain a creative, productive research environment?

A number of key personalities in the Institute's history figure in this account. Most Swedish readers would readily recognize them, but the appendix includes brief biographies of these people to aid non-Swedish readers.

What was accomplished at IUI?

Very little systematic empirical research was pursued in Sweden prior to the late 1920s. At that point in time Gösta Bagge, professor at Stockholm University, initiated a massive empirical project on national income and long-term economic growth in Sweden financed by the Rockefeller Foundation (Sandelin 1991). The project included the construction of consistent data series on wages, cost of living, national income and other key economic variables in Sweden from 1860 to 1930 (Bagge et al. 1933-37). It turned out that the project

\footnotetext{
${ }^{1}$ The English name of IUI was the Industrial Institute for Economic and Social Research until 1996, when the English name was changed to the Research Institute of Industrial Economics. It has usually been referred to as IUI in English. The Swedish name was changed to Institutet för Näringslivsforskning in 2006; since then, the new abbreviation IFN has been used.
} 
provided a good training ground in doing empirical work for a number of young Swedish economists, among them Erik Lundberg and Ingvar Svennilson.

At the end of the decade two empirically-oriented research institutes were founded: the governmental National Institute of Economic Research (Konjunkturinstitutet, KI) in 1937, and IUI two years thereafter. Headed by Erik Lundberg, KI concentrated on macroeconomic and public sector issues. For its part, IUI came to concentrate on the study of the determinants of industry growth. The Institute focused on individual companies and their owners very early. During Ingvar Svennilson's stint as CEO in 1941-49, IUI was quickly transformed into a research institute with an academically qualified staff. ${ }^{2}$ According to Svante Nycander $(2005,126)$, IUI and KI had «the reputation of being the country's foremost economic research institutes in the 1940s».

Few people in Sweden earned a Ph.D. in Economics before the 1970s. Eight doctorates were granted during the 1940s, and the number remained low in the 1950s and 60s with a total of 16 and 18 new doctorates, respectively (Wadensjö 1992). Moreover, no university institution offered regular postgraduate studies at this time. In light of this, it is impressive that eleven doctoral dissertations and fifteen licentiate dissertations were written at the Institute during its first 30 years (Nabseth 1969). ${ }^{3}$ IUI became thus an important site of education for economists.

With Ingvar Svennilson as CEO, IUI spearheaded the governmental Swedish Medium Term Surveys (Långtidsutredningarna, LU). In fact, Svennilson was chairman of the first commission (Åberg 2009). Moreover, IUI produced the socalled Industrial Supplement (Industribilagan) in collaboration with the Ministry of Finance through the beginning of the 1970s. IUI Deputy Director Erik Höök was appointed Director of Planning at the Ministry of Finance, with responsibility for precisely these medium term surveys. ${ }^{4}$ The surveys came to

\footnotetext{
${ }^{2}$ Ingvar Svennilson's contributions are described by Persson and Siven (2009).

${ }^{3}$ Before it became common to submit papers to international academic journals, writing dissertations for a Ph.D. or Licentiate degree substituted for the external scrutiny provided by the peer review process.

${ }^{4}$ Erik Höök defended a dissertation written at IUI on public sector expansion (Höök 1962).
} 
play a central role in Swedish economic policy making for several decades to come (Bergman, Heikensten and Lundgren 1991).

Yet IUI's collaboration with the government ended in the beginning of the 1970s, when political polarization made continued collaboration all but impossible (Wohlin 2009). At this point, IUI began conducting alternative Swedish medium term surveys (called Långtidsbedömningar), continuing for another two decades.

IUI also compiled new statistics for core economic areas such as construction (Salaj 1968), and the use of time in households (Klevmarken 2009). Statistics Sweden (SCB) has since assumed and further developed these IUI initiatives. However, IUI continued to compile and analyze unique data about Swedish enterprise. Birgitta Swedenborg, for example, began assembling a comprehensive database of the operations of multinational companies (e.g., Swedenborg 1979). ${ }^{5}$ These data-unique in an international perspective as well-have been kept up to date, providing the basis for a series of influential academic studies. ${ }^{6}$

Through the end of the 1960s, IUI produced a considerable amount of studies that directly affected company decision making — see Wohlin (2009) for an overview. For instance, Göran Albinsson Bruhner (2009) describes how the automobile, chemicals, and construction industries eagerly referenced industry studies and research reports.

Readers of older IUI studies are often struck by the skillful use of fundamental microeconomic theory, as well as the elegant style of writing. According to John Skår (2009), IUI was unique in Europe in the 1960s in this regard, comparable to the National Bureau of Economic Research (NBER, founded in 1920) in the United States. Indeed, the origins of the two institutions are similar: both were

\footnotetext{
${ }^{5}$ Among other things, it was shown that Swedish companies' investments in foreign countries did not negatively affect Swedish export. It consequently deposed the reason behind Swedish restrictions on outward foreign direct investment (Swedenborg 2009).

${ }^{6}$ See, for example, Andersson et al. (1996), Ekholm and Hakkala (2007), Heyman et al. (2007), and Norbäck (2001).
} 
established to collect, analyze, and disseminate facts concerning significant policy issues.

As underscored by Ove Granstrand (2009) among others, IUI has always been characterized by its dynamic perspective on economic problems and its ambition to analyze the interplay between micro- and macroeconomic factors. This was groundbreaking, especially because microeconomics and macroeconomics were largely separate subdisciplines until the 1970s. Granstrand maintains that the Stanford Institute of Economic Policy Research (SIEPR) was the only other research institute to encourage a similar approach.

At the beginning of the 1970s, IUI followed the lead set by Erik Dahmén's (1950a, 1970) dissertation on industrial enterprise and began research on the individual company and its founder-entrepreneur. IUI was the first institute in Sweden to conduct research in this area. Gunnar Du Rietz worked in Dahmén's footsteps throughout the 1970s, studying the causes and significance of firm entry in the Swedish postwar era (Du Rietz 1980; Hause and Du Rietz 1984). During the 1970s and 1980s, Bo Carlsson and Gunnar Eliasson studied entrepreneurship and industrial development. IUI was a forerunner in both Sweden and the world in this respect as well; these issues escaped serious international attention until the publication of David Birch's study in 1979. Dahmén's dissertation on structural change and economic development-which he wrote at IUI during the most of the 1940s — significantly contributed to what has been identified as a uniquely Swedish research tradition (Carlsson and Henriksson 1991; Pålsson Syll 1995; Johansson and Karlson 2002).

Yet the Institute's notability did not inspire the same feeling of prominence among its researchers, resulting in a culture of restraint when it came to “selling” results. Villy Bergström (2009), for instance, describes how Ragnar Bentzel made fundamental contributions that were only published in an obscure Festschrift in Swedish. ${ }^{7}$ Siv Gustafsson (2009) recalls how her fellow

\footnotetext{
${ }^{7}$ According to the life-cycle theory of savings - developed by Franco Modigliani and Richard Brumberg - there is a connection between specific cohort behavior and aggregate savings and consumption. Bentzel (1959) shows that, in the case of positive productivity growth, there will
} 
researchers considered her presumptuous when she sent her dissertation (written in Swedish with an English summary) to the famous Jacob Mincer at Columbia University together with a letter thanking him for his inspiration. In addition, Anders Klevmarken wrote his dissertation in English, but his main results were never published in a journal. When he visited the RAND Corporation's Finis Welch, a world-leading scholar in Klevmarken's field, a few years later, Welch picked Klevmarken's dissertation up off the shelf and frankly declared it an example of how a dissertation should not be written if people want their research to receive the attention it deserves (Klevmarken 2009).

The relatively modest attention accorded Birgitta Swedenborg for her pioneering work in data collection and research on multinational companies' operations and significance provides another example. She herself notes (Swedenborg 2009, pp. 344-345):

My dissertation contained many other things - it likely had enough material to inspire some academic papers in international journals. Research in this area was still in its infancy and my analyses were unique at this point in time. But such publication was prioritized by neither IUI nor myself.

A list of IUI reprints in English shows that international publication of IUI research was not emphasized until the 1980s. In fact, it did not become standard practice for researchers at IUI/IFN to publish internationally until the $1990 \mathrm{~s}^{8}$

So how was an industrial survey bureau transformed into an eminent research institute?

\footnotetext{
be a positive correlation between growth and savings due to higher lifetime resources, and therefore savings, of younger cohorts relative to the dissaving of retired cohorts. In his Nobel Prize lecture, Franco Modigliani (1986) acknowledges this contribution and names it "the Bentzel effect."

${ }^{8}$ A similar situation prevailed at university institutions throughout Sweden. Under the leadership of Assar Lindbeck, the Institute for International Economic Studies (IIES) first began systematically publishing in international journals in the middle of the 1970s. This practice then spread to other institutions and institutes. Swedes who returned to Sweden after earning their doctorate in the USA in the beginning of the 1970s also exerted an important influence in this respect (Jonung 1992).
} 


\section{Independence}

Scholarly independence is a prerequisite for high-quality academic research.

This standard also became a natural part of IUI research, despite that trade and industry interest groups effected its founding, and that an employers' confederation still provides base funding. The early efforts of Sigfrid Edström and Ingvar Svennilson were crucial in this regard. Both were extraordinarily powerful and forceful, and both had the ability to push through their demands. Despite resistance from employers' organizations (Henriksson 1990), Edström succeeded in establishing the Institute. When Svennilson was appointed CEO, he had Edström's full support to transform the survey bureau into a research institute, even though the transformation would result in more diffuse benefits for the Institute's principals. There ran an obvious risk that research results would at times conflict with the principals' interests.

As articles and lectures from this time clearly illustrate, Svennilson was deeply convinced of the potential of economic research to contribute to better general living conditions. He was also sure that Swedish industry underpinned this process (see, for example, Svennilson 1942a, 1942b).

Several consequences followed naturally from the decision to convert IUI into a research institute: studies would have to fulfill requirements of scholarly quality; it would be necessary to accept long-term and time-consuming projects; andmost importantly — it would be necessary to accept and even require research results to be published. As Jan Wallander (2009, p. 67) writes:

One can say that the principle of publication was the most crucial. In following that principle, it soon became apparent that requirements of quality would be fulfilled — one could never suspect that less "appropriate" results were suppressed.

Jan Wallander personally experienced what Svennilson's defense for this principle entailed. Wallander had just finished collecting primary data for a study financed by the company Uddeholm about the depopulation of the province of Wermland's forested areas. Headed by Swedish businessman Nils Danielsen, the company pressed Jan Wallander to end the study and place what 
he had finished so far "in the desk drawer." ${ }^{\text {9 }}$ Svennilson reacted immediately and forcefully, making it clear to Danielsen that IUI was a research institute and that Uddeholm was in no position to bar publication of any results.

Another person central to the development of IUI was Erik Dahmén, whose influence on the Institute began in the early 1940s and continued for another 50 years. Because Dahmén wrote his doctoral dissertation at IUI during Svennilson's time as CEO, he was present when Svennilson launched and defended the immutable principle of scholarly publication. Dahmén became acting director in 1949 and earned his doctorate in 1950. In the IUI book Industriproblem 1950, he wrote (pp. 7-8):

It was already clear from the start that [IUI's work] had to be pursued apolitically and on a scientific basis in order to serve its purpose. ... Limiting tasks to service-related surveys would apart from this fact [the difficulty of recruiting qualified staff] be hard to carry out, however. It would also be unsuitable for another reason, namely that research activity of a more long-term quality is a prerequisite for effective service activity.

Dahmén thereby clearly established that scholarship and its subsequent publication were necessary for securing high quality analysis. At this point, Dahmén became personal advisor to Swedish industry's premier Marcus Wallenberg (1899-1982), a position he would hold for the remainder of Wallenberg's life. In 1950, Marcus Wallenberg began his 25-year-long chairmanship of the IUI board. The anniversary volume offers a large number of examples of how Wallenberg defended both researchers' academic freedom and the principle that even unappreciated results would be publishedunconditionally. In one case described in the volume, Wallenberg sanctioned the publication of results (of an inquiry that he had commissioned and financed) that strongly went against his own interests.

While presiding over the Centre for Business and Policy Studies (Studieförbundet Näringsliv och Samhälle, SNS), Jan Wallander established the same principles there, and later implemented and consolidated these principles

\footnotetext{
${ }^{9}$ The whole incident is described in Wallander (1997, pp. 202-205). At this time, Nils Danielsen was also a member of the IUI board. In addition, he was chairman of the Federation of Swedish Industries (Industriförbundet) in 1947-49.
} 
as CEO at IUI from 1953 to 1961. Åke Sundström ${ }^{10}$ recalls how Jan Wallander often quoted philosopher Benjamin Höijer in order to strengthen morale, especially his answer to a friend who warned about the perils of unbiased thinking: "Seek the truth! And if it leads you to the gates of hell, knock on the door."

Several essays in the volume illustrate how IUI CEOs have defended researchers against outside pressure (often with the support of the chairman of the board). Perhaps the best known example of this occurred when Sven Hammarskiöld, CEO of the company Sockerbolaget (the Swedish sugar monopoly), resigned his post on the board in protest against Odd Gulbrandsen's and Assar Lindbeck's investigation of agricultural policy (Gulbrandsen and Lindbeck 1966; see also Lindbeck 2009). Another telling example is Bo Carlsson's starkly critical contribution to public debate in the mid-1970s about industry's "12 Nuclear Reactor Program," which came highly recommended by then ASEA CEO and later IUI chairman (1984-93) Curt Nicolin. ${ }^{11}$

Arriving at the Institute as a researcher in 1948, Jan Wallander's successor Ragnar Bentzel was schooled in the same spirit of academic freedom. In his account, Villy Bergström (2009) highlights Bentzel's qualities as an intellectual leader, inspiration, and discussion partner, among other things. Göran Albinsson Bruhner (2009, p. 202) describes him ("Naja") in the following manner:

Naja's leadership style was a pure reflection of his warm and generous personality. In my memories, Naja stands out as one of the least egocentric people I have ever met. Assured of the scope and depth of his own confidence, he supported his novices and let them receive the honor of grasping ideas and analyses that actually emanated from himself.

In describing Bentzel, Gunnar Törnqvist (2009b) even draws parallels to the physicist Niels Bohr and his legendary Institute in 1920s Copenhagen. ${ }^{12}$

\footnotetext{
${ }^{10}$ In private e-mail correspondence with the article's author, December 5, 2008.

${ }^{11}$ See, for example, Carlsson (1977).

12 The German physicist Erwin Schrödinger coined the term Kopenhagener Geist to describe this legendary research environment.
} 


\section{Societal relevance}

Because of IUI's close connection to Swedish industry, policy relevance and social value guided the Institute in setting its research agenda. The so-called third objective, ${ }^{13}$ which was only incorporated into university research in later years, has been a given at IUI since its inception.

IUI scholars were motivated by their interest in Swedish industry rather than methodology. They were inspired by the knowledge that their research was significant in a wider setting, outside the academic world. This fits well with Csikszentmihalyi's (1996) thesis, namely that productive creativity-innovative work that has broad impact and is generally recognized-arises when three elements interact: the field, the individual, and the expertise. The latter two determine who gains access to the field. Csikszentmihalyi studies why painting, architecture, and sculpture suddenly exhibited such creativity in $15^{\text {th }}$ century Florence. In all likelihood, a larger amount of gifted artisans did not live there and then than at any other place or time. Instead, two conditions had changed: the field had been transformed through the rediscovery of classical knowledge, and demand among Florence's ruling class had suddenly shifted to art and architecture. ${ }^{14}$ Combined with greatly increasing demand from sophisticated buyers, productive creativity blossomed.

Drawing an analogy to today's research is not as far-fetched as one might think. The academic freedom that prevails in a good research environment entices researchers to spontaneously migrate to areas where demand for analysis and new findings is great. This demand arises from a complicated interplay between societal progress, the feasibility of researching certain issues, and what potential financiers are prepared to support. To a large extent, IUI research is driven by external demands and stimuli rather than being mostly determined by academia's internal acceptance. Yet, the academic research community constitutes an important part of the demand, namely the demand for research of

\footnotetext{
${ }^{13}$ The first two objectives are research and teaching. The third objective refers to collaboration with surrounding society and the act of disseminating research outside academia. This objective became Swedish law on July 1, 2009, through a change in the Higher Education Act (Högskolelagen).

${ }^{14}$ See Eliasson and Eliasson (1997) for an analysis of the crucial role of buyers' competence in the artistic creativity of $15^{\text {th }}$ century Florence.
} 
high academic quality. Two other successful Swedish research environmentsthe Institute for Labour Market Policy Evaluation (IFAU) and the Research Department of the Swedish Central Bank (Riksbankens forskningsavdelning) are also largely guided by societal relevance when selecting their research problems.

The researchers' conviction that IUI's work was significant and made a difference was fundamental to its success. Indeed, Klamer and Colander (1990) came to a similar conclusion when researching the personal development of doctoral students at leading American universities. They found that doctoral students at the University of Chicago were the most satisfied because professors succeeded in conveying the importance of what the students researched and learned. Incidentally, the University of Chicago has also fostered the largest number of Nobel laureates in economics (Törnqvist 2009a, ch. 11).

Perhaps this spirit—-stemming from something as basic as a keen interest in social matters - is more durable than the fellowship formed in certain research groups around specific methods or more confined issues.

\section{The IUI spirit}

The fact that researchers felt free to seek answers to the best of their ability when a project was approved by the board (the prevailing procedure up until the mid-1990s) was crucial to IUI's success. The "IUI spirit," described by so many contributors to the anniversary volume, could in turn develop through the Institute's great resources and well-administered workplace, especially when compared to universities.

The IUI spirit cannot be easily defined, but I believe it originated in the researchers' knowledge that neither director nor financier or principal could violate their integrity as scholars. At the same time, the researchers' work ethic had to be such that they were not tempted to abuse this privilege by underperforming either qualitatively or quantitatively. 
In this regard, team spirit became especially important. IUI researchers felt proud of their Institute, and so took responsibility for advancing each other's research through sometimes heavy-handed yet essentially constructive critique. ${ }^{15}$ Lunch and coffee breaks served as informal seminars, and both formal weekly meetings and multi-day workshops at alpine hotels or other secluded places were held where every detail of extensive manuscripts was painstakingly penetrated. No hierarchy applied there. The opinions of Ragnar Bentzel and Research Director Erik Höök may have carried particular weight because of their acumen and expertise, but their own research was reviewed in the same rigorous, frank fashion as everyone else's (Vinell 2009).

The Institute did not have an elaborate formal hierarchy, which led to a lack of the internal competition for positions that marks most universities. As a result, IUI was spared from destructive fights over academic turf. Moreover, IUI had the freedom to recruit researchers whose interests and subject area harmonized with the Institute; these new researchers would then contribute to the Institute in its entirety. This contrasted sharply with governmental institutes' inflexible rules in regard to job appointments. Indeed, IUI's flexibility enabled the creation of research groups composed of individuals who were genuinely interested in their colleagues' research and also had the expertise to give useful feedback.

Other features also distinguished IUI from institutions of higher education. The first was the presence of multidisciplinary competence in the same corridor. Economists who worked with empirical material, for instance, could easily get help from statisticians. Until the 1960s, the IUI research staff included the disciplines of sociology, law, economic geography, agricultural economics, and business administration.

IUI's third distinguishing feature was its infrastructure. In the present age of personal computers and the Internet, all researchers have access to powerful tools for computation, editing, and seeking information. But not long ago, IUI researchers had the advantage of being able to receive extensive internal

\footnotetext{
${ }^{15}$ See especially Erik Ruist (2009) and Bengt Rydén (2009).
} 
assistance with routine tasks. IUI's support staff performed a multitude of timeconsuming tasks, such as manually computing regressions, typing letters and manuscripts, coding questionnaires, and so forth, leaving the researchers with more time to explore questions in depth.

IUI also invested extensively in various analytical tools. During the 1970s and the 1980s, IUI developed three econometric models of the Swedish economy. The models were based on radically different premises, and could be used to give alternate predictions of the effects of different economic policy measures. Gunnar Eliasson (2009, p. 143) writes:

The models provided different answers to nearly every question that was put to them, which clearly illustrated what a priori conditions signify for all analytical results, including the extent of uncertainty and not least how little policymakers know about the likely effects of their measures.

Researchers were perhaps not always aware of their privileged position while still at IUI, but they tended to see things differently after moving to "more normal" environments. Lars Lidén (2009, p. 256) provides a telling illustration:

Later in life, I sat on the boards of various governmental investigations with politically recruited chairmen, with directives that had been formulated in some ministry and where all committee members had been recruited along strict partisan lines. I often thought then with a tinge of regret about how unbureaucratic and accepting things had been at IUI. Perhaps more so than before, I realized the value of having a private, nonpartisan research institute within the confederation of Swedish enterprise.

\section{Surroundings and mobility among researchers}

Gunnar Törnqvist, a professor of economic geography at Lund University who was active at IUI during the mid-1960s, has recently conducted research on the characteristics of creative research environments (Törnqvist 2009a). In his contribution to the anniversary volume, Törnqvist (2009b) applies these insights to his own experiences at IUI. He maintains that successful research environments are clearly elitist, yet not in its formal meaning (hierarchical ambition) but rather in how they strive to be best in comparison with outside actors. These environments are filled with people who are passionate about the research problems they have chosen. 
Inventive researchers with genuine, field-specific scientific competence are attracted to environments in which conditions for renewal and personal growth are favorable. In such environments, researchers can pose truly fruitful questions while remaining conscious of the boundaries between different specialties.

Törnqvist (2009b, pp. 296-297, italics in original) also writes that:

International surveys show that creativity develops best in small, egalitarian organizations ... At the same time, it is of great advantage for these small environments to be surrounded and supported by strong economic resources. The ideal size of a creative environment varies, but groups of four to seven researchers are common. Such small environments work best if they are included within a larger research community through strategic links with other environments and networks. ${ }^{16}$

Upon closer examination of these [creative] environments, an apparently contradictory combination of cooperation and rivalry appears. In such blessed places it is possible to have generosity, equality, and competition at the same time... In my time, some researchers had greater influence than others. But their intellectual authority did not depend on formal positions, but rather on richness of ideas, knowledge, and their ability to inspire others. IUI was not an arena for internal competition.

IUI researchers came to be characterized by two important aspects: mobility and turnover. In an organization lacking mobility and the influx of new people, both the conception of what is correct and the measure of what makes good research can easily stiffen - a sort of internal consensus emerges, leaving researchers contented with what they happen to be doing. ${ }^{17}$ The influx of new competence and outside contacts prevents this from occurring; researchers are instead forced to pursue best practice.

At the outset, this essay asked what was accomplished at IUI. For a research institute with high mobility and dynamism, the subsequent careers of former IUI staff — and how these careers were influenced by their time at IUI-form an important part of the answer.

\footnotetext{
${ }^{16}$ Stockholm and Uppsala today are characterized by high quality postgraduate programs in economics and several distinguished research environments. In spring 2009, there were slightly more than 280 active researchers with doctorates in economics (including finance) and roughly 210 doctoral students at Stockholm and Uppsala.

${ }^{17}$ Cf. Klein and Stern's (2009) analysis of how American elite universities nearly exclusively recruit from one another. At the same time, this inner circle decides what is worth researching and what is good research; the risk of creating a closed system is obvious.
} 
IUI research has been propagated as researchers have moved to new academic environments. One example is Bo Carlsson, whose experiences, insights, and contacts garnered at IUI laid the foundation for his subsequent research at Case Western Reserve University in Cleveland, Ohio. Bo Carlsson was also the driving force behind the establishment of the new field of Industrial Dynamics (Carlsson 2009).

It is easy to find more examples. Albert Danielsson and Ove Granstrand have played an important role in advancing the role of economic research at Sweden's two leading institutes of technology. Bengt-Christer Ysander's move from IUI to a professorship at Uppsala University initiated a substantial shakeup of the research environment there. Lars Lundberg became the first professor of economics at Örebro University and has since built a research group in international economics there. Jan Södersten became professor at Uppsala University and later the leading expert of corporate taxation, and has guided a large number of doctorate students in this area. Likewise, Bertil Holmlund became professor at Uppsala and established one of Europe's leading research environments within labor economics. In 2008 he also became chairman of the Nobel Prize Committee. Anders Björklund became professor at Stockholm University and a leading authority on intergenerational income mobility. Margit Cassel and Karin Kock were the first women in Sweden to earn doctorates in economics (in 1924 and 1929); Siv Gustafsson was the third (in 1976). She later became a pioneer in feminist economics and thereafter professor at the University of Amsterdam, where she formed her own research group (Gustafsson 2009).

Throughout the 1970s, IUI researchers played an important role as expert examiners and critics of the effects of an increasingly complicated and distortionary tax system. Ulf Jakobsson and Göran Normann demonstrated that the so-called Haga Agreements (1974-75), in which the government and social partners (trade unions and the employers' confederation) agreed to exchange lower income tax for higher social security contributions, would not exert the positive effects claimed by its proponents. Göran Normann illustrated the impossibility of using a production factor tax to shift the tax burden from 
personal income tax to levying more taxes "directly on production" instead (Normann 2009). Together with the research performed by Jan Södersten and several other IUI researchers, these analyses figured greatly for Swedish Trade Union Confederation (LO) chairman Stig Malm and Minister of Finance KjellOlof Feldt, who explained to a startled audience in a November 1988 press conference that the Swedish tax system was "rotten" and "perverse.",18

Researchers applied their IUI schooling in critical, well-founded research in other settings after they left the Institute. For example, Bengt Rydén (2009, pp. 329-330) writes:

My schooling in research at IUI became crucial for my entire subsequent professional life. I was trained to formulate problems, evaluate relevance, consider things from different perspectives, pose questions, and be systematic and structured in my own work. "Why can't it be the opposite?" represented an approach that I acquired then that followed me throughout my entire life, often to the chagrin of my colleagues.

Similar formulations can be found in several of the contributions written by people who pursued a purely business-oriented career after their time at IUI; see, for example, Staffan Håkanson (2009) and Jan Wallander (2009).

Åke Ortmark (2009, p. 239) relates how he retained the same thinking when he entered into journalism: "The great lesson from the Institute was that one cannot be careless when speaking about something as important as reality." Together with professional economist Herbert Söderström, Ortmark introduced the socalled hard-hitting form of journalism (skjutjärnsjournalistiken) that fundamentally changed Swedish journalists' way of treating the powerful and their motives.

IUI also influenced another organization that set the tone of policy discussions and business research in postwar Sweden: the Centre for Business and Policy Studies (SNS). Two of the three main architects behind SNS - Axel Iveroth and Tore Browaldh—had been schooled at IUI, and Jan Wallander, SNS's first actual president, had written his dissertation at the Institute. When Wallander became head of IUI in 1953, fellow IUI researcher Hans B. Thorelli filled his

\footnotetext{
${ }^{18}$ Feldt (1991, p. 386).
} 
shoes as president of SNS; after him, IUI researcher Torsten Carlsson became president. After an interlude of two short-lived presidents, Göran Albinsson Bruhner and later Bengt Rydén headed SNS. Thus, for nearly 30 of SNS's first 36 years, the organization was headed by former IUI researchers (Ullenhag 1998). Stefan Lundgren, the president of SNS from 2003 to 2009, was active at IUI at the end of the 1980s. In later years, IUI researchers Birgitta Swedenborg and Pontus Braunerhjelm also held leading posts at SNS.

Finally, it should be mentioned that the existence and success of IUI was decisive in LO's 1981 congress decision to consider the possibility of establishing a trade union-based institute of economic research. Among those conducting the investigation was Bengt-Christer Ysander, a senior researcher at IUI at the time. ${ }^{19}$ The investigation (Swedish Trade Union Confederation 1984) presented its report in 1984; one year later, the Trade Union Institute for Economic Research (FIEF) was founded, with previous IUI researcher Villy Bergström at its head. ${ }^{20}$ According to Villy Bergström (1997, p. 8), LO needed

an interface towards the research community. Industry had had it ever since the establishment of the Industrial Institute for Economic and Social Research (IUI). Nearly all Swedish economists had worked at IUI at some point or had been in contact with the Institute. As a result, industry had extensive contacts among leading researchers.

The alumni list in the anniversary volume includes about 230 previous IUI researchers in total. A fourth of these researchers pursued subsequent careers in the business sector (including the media) and another fourth worked in the public sector; about 35 percent continued their academic careers elsewhere, mostly as university professors, and nearly one in eight worked for interest groups.

\section{Conclusion}

In connection with the $70^{\text {th }}$ anniversary of IFN/IUI, a large number of previous IUI researchers were invited to write personal essays about what their time at

\footnotetext{
${ }^{19}$ In this regard, see the contribution by IUI's then CEO Gunnar Eliasson (2009, p. 144).

${ }^{20}$ Given its limited resources, FIEF was exceptionally successful in many ways, especially during the institute's first ten years-see Bergström (1997). Because of the decline of unionization and the resultant drop in revenue, FIEF was dismantled at the end of 2005 after 20 years of existence.
} 
IUI meant for their professional and personal development. This resulted in an extensive collection, which constitutes the main source of this account.

In this essay, I have attempted to document IUI's success and importance. The evolution of the Institute constitutes an example of the "sociology and professionalization of economics" (Coats 1993). Its significance for Swedish social science research and policy discussion is striking. But it becomes increasingly difficult to review IUI's accomplishments as we near the present day. Likewise, doing so is doubly difficult for somebody who is deeply engaged in the Institute's current activities. For this reason, the most recent decades have not been discussed in detail.

IUI was founded when industry realized that economic research may be useful. The account shows that there may be a close cooperation between such institutes, universities, and government. The Institute has regularly been engaged in government reports and many doctoral dissertations have been written at IUI and defended at the universities. At the beginning of the 1970s, when political polarization was strong in the whole Western world, collaboration with government ceased. International publication-a step in the process of professionalization-became emphasized in the 1980s.

Which factors were key to the Institute's success? The first decisive condition was the existence of a handful of individuals who possessed a clear vision for what they wanted to accomplish and the ability to implement this vision, coupled with a vibrant interest in social matters. From the very start, they aimed to satisfy both the principals' and other financiers' demands for relevance and researchers' and academia's demands for integrity and high scientific quality.

The Institute never deviated from a number of important and immutable principles that were established at its inception. The most important of these was that all results would be unconditionally published once they passed careful peer scrutiny to ascertain that quality standards were met. ${ }^{21}$ Researchers in turn

\footnotetext{
${ }^{21}$ While this may seem self-evident today, it is still not always the case. See, for example, Mandel (1999), who discusses the danger involved in economic researchers' lucrative consulting
} 
assumed a strong sense of self-confidence, inspiring them to seek the truth to the best of their ability, and to publish their findings irrespective of which interests they challenged.

The Institute's management also succeeded in establishing a creative research environment. IUI lacked formal hierarchies; it was everyone's collective responsibility to boost the quality of researchers' reports via demanding formal and informal reviews. The Institute's creativity also gained from the influx of new researchers who had contacts outside its sphere.

The IUI spirit was not connected to a particular theory, method, or school of thought. Rather, it was based upon a distinctive approach to economic problems, namely that all of the Institute's research problems should have broad, nonacademic relevance. As a result, people beyond academia came to demand IUI's research, including financiers, politicians, and leading actors in business and enterprise. IUI thrived in part because of this outside demand, which has been shown to be greatly conducive for both creativity and productivity.

\section{References}

Albinsson Bruhner, Göran (2009), “Gyllene år”. In Henrekson, ed. (2009).

Andersson, Thomas, Torbjörn Fredriksson and Roger Svensson (1996), Multinational Restructuring, Internationalization and Small Economies - The Swedish Case. London and New York: Routledge.

Bagge Gösta, Erik Lindahl, Erik Lundberg, Gunnar Myrdal, Ingvar Svennilson et al. (1933-37), Stockholm Economic Studies, Vol. 1-3, London, P. S. King.

Bergman, Lars, Lars Heikensten and Stefan Lundgren (1991), "Långtidsutredningarnas metodik och roll i den ekonomiska politiken." In Ekonomi och samhälle 2: Ekonomisk tillväxt och utveckling (Festschrift to Karl G. Jungenfelt's 60th birthday). Stockholm: SNS Förlag.

Bentzel Ragnar 1959, "Några synpunkter på sparandets dynamik.” In Festskrift tillägnad Halvar Sundberg. Uppsala: Almqvist \& Wiksell.

Bergström, Villy (1997), "Inledning." In Villy Bergström, ed., Arbetsmarknad och tillväxt. Tio års forskning med facket. Stockholm: Ekerlids Förlag.

Bergström, Villy (2009), "Ragnar Bentzel: Forskaren, handledaren, vännen." In Henrekson, ed. (2009).

assignments for individual companies in antitrust cases. Medical research financed by pharmaceutical companies is also common, for example. There now exists a great deal of support for lopsidedness in terms of which results get published; see, for example, Melander $e t$ al. (2003) and Turner et al. (2008). 
Birch, David L. (1979), The Job Generation Process. Cambridge, MA: MIT Program on Neighborhood and Regional Change.

Carlsson, Bo (1977), ’Hur håller vi produktionen uppe och sparar energi?”. In Energipolitik för framtiden. Stockholm: Näringslivets Energidelegation.

Carlsson, Bo (2009), "Reflektioner om min tid på IUI." In Henrekson, ed. (2009).

Carlsson, Bo, and Rolf Henriksson (1991), Development Blocks and Industrial Transformation: The Dahménian Approach to Economic Development. Stockholm: IUI.

Coats A. W. Bob (1993), The Sociology and Professionalization of Economics. London and New York: Routledge.

Csikszentmihalyi, Mihály (1996), Creativity: Flow and the Psychology of Discovery and Invention. New York: Harper Collins.

Dahmén, Erik (1950a), Svensk industriell företagarverksamhet: kausalanalys av den industriella utvecklingen 1919-1939. Stockholm: IUI.

Dahmén, Erik (1950b), "Ekonomiska utredningar och ekonomisk forskning till industriens tjänst. En översikt över verksamheten vid Industriens Utredningsinstitut." In Industriproblem 1950. Stockholm: IUI.

Dahmén, Erik (1970), Entrepreneurial Activity and the Development of Swedish Industry, 1919-1939. Translated by Axel Leijonhufvud for the American Economic Association. American Economic Association translation series. Homewood, IL: Richard D. Irwin.

Du Rietz, Gunnar (1980), Företagsetableringarna under efterkrigstiden. Stockholm: IUI and Almqvist \& Wiksell.

Ekholm, Karolina, and Katariina Hakkala (2007), "Location of R\&D and High-Tech Production by Vertically Integrated Multinationals". Economic Journal, Vol. 117, No. 518, 512-543.

Eliasson, Gunnar (2009), 'IUI - en privat akademi." In Henrekson, ed. (2009).

Eliasson, Gunnar, and Ulla Eliasson (1997), Företagandets konst: om konstproduktionen i renässansens Florens. Stockholm: City University Press.

Feldt, Kjell-Olof (1991), Alla dessa dagar... I regeringen 1982-1990. Stockholm: Norstedts.

Granstrand, Ove (2009), "Vad IUI betytt för mig." In Henrekson, ed. (2009).

Gulbrandsen, Odd, and Assar Lindbeck (1966), Jordbrukspolitikens mål och medel. Stockholm: Aldus/Bonniers.

Gustafsson, Siv (2009), ’Du är en av oss. Personliga IUI-minnen 1967-1980.” In Henrekson, ed. (2009).

Håkanson, Staffan (2009), ’En ingenjör bland ekonomer: IUI 1967-1970.” In Henrekson, ed. (2009).

Hause, John C., and Gunnar Du Rietz (1984), "Entry, Industry Growth, and the Microdynamics of Industry Supply." Journal of Political Economy, Vol. 92, No. 4, 733-757.

Henrekson, Magnus, ed. (2009), IFN/IUI 1939-2009. Sju decennier av forskning om ett näringsliv $i$ utveckling. Stockholm: Ekerlids Förlag.

Henriksson, Rolf G. H. (1990), Som Edström ville - Hur IUI blev till. Stockholm: IUI.

Heyman, Fredrik, Fredrik Sjöholm and Patrik Gustavsson Tingvall (2007), "Is There Really a Foreign Ownership Wage Premium? Evidence from Matched EmployerEmployee Data." Journal of International Economics, Vol. 73, No. 2, 355-376.

Höök, Erik (1962), Den offentliga sektorns expansion: En studie av de offentliga civila utgifternas utveckling åren 1913-58. Stockholm: IUI and Almqvist \& Wiksell.

Johansson, Dan, and Nils Karlson (2002), Den svenska tillväxtskolan: om den ekonomiska utvecklingens kreativa förstörelse. Stockholm: Ratio. 
Klamer, Arjo, and David Colander (1990), The Making of an Economist. Boulder och London: Westview Press.

Klein, Daniel B. and Charlotta Stern (2009), "Groupthink in Academia. Majoritarian Departmental Politics and the Professional Pyramid." Independent Review, Vol. 13, No. 4, 585-600.

Klevmarken, Anders (2009), "Forskare på IUI under en tid då nya metoder och data förnyade den empiriska forskningen." In Henrekson, ed. (2009).

Lidén, Lars (2009), "IUI under senare hälften av 1950-talet." In Henrekson, ed. (2009).

Lindbeck, Assar (2009), ”Assar minns: mina tre perioder på IUI.” In Henrekson, ed. (2009).

Mandel, Michael J. (1999), "Going for the Gold: Economists as Expert Witnesses." Journal of Economic Perspectives, Vol. 13, No. 2, 113-120.

Melander, Hans, et al. (2003), "Evidence B(i)ased Medicine - Selective Reporting from Studies Sponsored by Pharmaceutical Industry: Review of Studies in New Drug Applications." BMHJ, Vol. 326, 1171-1173.

Modigliani, Franco (1986), 'Life Cycle, Individual Thrift, and the Wealth of Nations".American EconoOmic Review, Vol. 76, No. 2, 297-313.

Nabseth, Lars (1969), "Industriens Utredningsinstitut 1939-1969." In Verksamhetsåret 1969. Institutets verksamhet under 30 år. Stockholm: IUI.

Normann, Göran (2009), ’Tillväxtår vid IUI.” In Henrekson, ed. (2009).

Norbäck, Per-Johan (2001), "Multinational Firms, Technology and Location.” Journal of International Economics, Vol. 54, No. 2, 449-469.

Nycander, Svante (2005), Från värdeteori till välfärdsteori. Nationalekonomin vid Stockholms Högskola/Stockholms universitet 1904-2004. Stockholm: SNS Förlag.

Ortmark, Åke (2009), "Att träna in en attityd." In Henrekson, ed. (2009).

Persson, Mats, and Clas-Henrik Siven (2009), "Ingvar Svennilson 1908-1972." In Henrekson, ed. (2009).

Pålsson Syll, Lars (1995), Den strukturanalytiska skolan i Lund: en essä om Johan Åkerman, Erik Dahmén, Ingvar Svennilson och ekonomisk teori- och metodutveckling. Lund: Ekonomisk-historiska föreningen.

Ruist, Erik (2009), ”Sex år på Malmtorgsgatan 8." In Henrekson, ed. (2009).

Rydén, Bengt (2009), 'IUI - min forskarskola." In Henrekson, ed. (2009).

Salaj, Branko (1968), Bostadsproduktionens prisutveckling. Stockholm: IUI and Almqvist \& Wiksell.

Sandelin B. 1991, «Beyond the Stockholm School», in B. Sandelin (ed.) 1991, The History of Swedish Economic Thought, London and New York, Routledge, 214224.

Skår, John (2009), "IUI - återblickar från framtiden." In Henrekson, ed. (2009).

Svennilson, Ingvar (1942a), "Behovet av ekonomisk forskning." Nationalekonomiska Föreningens Förhandlingar 1942, 57-62.

Svennilson, Ingvar (1942b), "Ekonomisk forskning för näringslivet." Tiden, Vol. 35, No. 6, 361-363.

Swedenborg, Birgitta (1973), Den svenska industrins investeringar i utlandet, 19651970. Stockholm: IUI.

Swedenborg, Birgitta (1979), The Multinational Operations of Swedish Firms - An Analysis of Determinants and Effects. Doctoral Dissertation. Stockholm: IUI.

Swedenborg, Birgitta (2009), "Mina år på IUI: 1969-81 och 1986-90.” In Henrekson, ed. (2009).

Swedish Trade Union Confederation [Landsorganisationen] 1984, Ett fackligt institut för ekonomisk forskning, Utredning på uppdrag av Landssekretariatet om inrättande av ett fackligt forskningsinstitut, Stockholm, LO. 
Turner, Erick H. et al. (2008), "Selective Publication of Antidepressant Trials and Its Influence on Apparent Efficacy." New England Journal of Medicine, Vol. 358, No. 3, 252-260.

Törnqvist, Gunnar (2009a), Kreativitet i tid och rum. Processer, personer och platser. Stockholm: SNS Förlag.

Törnqvist, Gunnar (2009b), "IUI i retrospektiv." In Henrekson, ed. (2009).

Ullenhag, Kersti (1998), I takt med tiden. SNS åren 1948-1998. Stockholm: SNS Förlag.

Vinell, Lars (2009), "Ingen samstämmighet - så bra för kreativiteten!” In Henrekson, ed. (2009).

Wadensjö, Eskil (1992), "Recruiting a New Generation" and "Appendix D." In Lars Engwall, ed., Economics in Sweden: An Evaluation of Swedish Research in Economics. London and New York: Routledge.

Wallander, Jan (1997), Livet som det blev. En bankdirektör blir till. Stockholm: Albert Bonniers Förlag.

Wallander, Jan (2009), "Mina år vid IUI.” In Henrekson, ed. (2009).

Wohlin, Lars (2009), "IUI och dess verksamhet fram till 1976. Specialiserad empirisk forskning eller övergripande samhällsanalyser?.” In Henrekson, ed. (2009).

Åberg, Carl Johan (2009), ’Långtidsutredningarna - en blandekonomins spegel.” In Henrekson, ed. (2009). 


\begin{tabular}{|c|c|c|}
\hline & At IUI & Subsequent Career in Brief \\
\hline $\begin{array}{l}\text { Göran Albinsson } \\
\text { Bruhner }\end{array}$ & 1955-66 & $\begin{array}{l}\text { President, Center for Business and Policy Studies (SNS); Editor, Svenska Dagbladet; Editor-in-Chief, Dagens } \\
\text { Industri; Senior Columnist, Svenska Dagbladet. }\end{array}$ \\
\hline Ragnar Bentzel & $\begin{array}{l}1948-52, \text { CEO } \\
1961-66\end{array}$ & $\begin{array}{l}\text { Associate Professor, Uppsala University; Professor, Stockholm School of Economics; Professor, Uppsala University. } \\
\text { Had a leading role in several government inquiries and commissions in the 1950s and 60s. }\end{array}$ \\
\hline Villy Bergström & 1965-69 & $\begin{array}{l}\text { Lecturer, Uppsala University; Founder and President, Trade Union Institute of Economic Research; Editor-in-Chief, } \\
\text { Tiden and Dala-Demokraten; Vice Governor, Swedish Central Bank. Has been an influential Social-Democratic } \\
\text { opinion leader since the 1960s. }\end{array}$ \\
\hline Anders Björklund & 1983-89 & Professor, Stockholm University. \\
\hline Pontus & 1989-99 & Vice President, Center for Business and Policy Studies (SNS); Professor of International Business and \\
\hline Braunerhjelm & & $\begin{array}{l}\text { Entrepreneurship, Royal Institute of Technology; Head, Ministry of Education Globalization Council (2007-09); } \\
\text { President, Swedish Entrepreneurship Forum (2008-). }\end{array}$ \\
\hline Tore Browaldh & $1944-45$ & $\begin{array}{l}\text { General Secretariat of the European Council, Strasbourg; Vice President, Confederation of Swedish Enterprise (SAF); } \\
\text { President and subsequently Chairman, Handelsbanken. Co-founder of the Center for Business and Policy Studies } \\
\text { (SNS). }\end{array}$ \\
\hline Bo Carlsson & $1972-84$ & Professor, Case Western Reserve University, Cleveland, Ohio. \\
\hline Erik Dahmén & $1942-50$ & Professor, Stockholm School of Economics; advisor to Marcus Wallenberg and Stockholms Enskilda Bank. \\
\hline J. Sigfrid Edström & Chairman 1939-43 & $\begin{array}{l}\text { President and subsequently Chairman, Asea 1903-49; Chairman, Confederation of Swedish Enterprise (SAF). } \\
\text { Founder of IUI. Legendary leader in Swedish industry and in the international sports movement, notably chairman of } \\
\text { the International Olympic Committee 1946-52. }\end{array}$ \\
\hline Gunnar Eliasson & $\begin{array}{l}\text { 1965-69, CEO } \\
1976-1994\end{array}$ & $\begin{array}{l}\text { Chief Economist, Federation of Swedish Industries (1970-75); Professor, Royal Institute of Technology; Research } \\
\text { Scholar, Ratio Institute. }\end{array}$ \\
\hline Ove Granstrand & 1981-93 & Professor of Industrial Management and Economics at Chalmers University of Technology, Gothenburg. \\
\hline Odd Gulbrandsen & $1952-57,1967-69$ & $\begin{array}{l}\text { Associate Professor, Swedish University of Agricultural Sciences (Ultuna), 1958-66. FAO; Research Director, } \\
\text { UNCTAD; Professor of Economics, Swedish University of Agricultural Sciences (Ultuna). }\end{array}$ \\
\hline Siv Gustafsson & $1967-80$ & Research Scholar, Institute for Working Life; Professor of Gender Economics, University of Amsterdam. \\
\hline Bertil Holmlund & $1976-85$ & $\begin{array}{l}\text { Associate Professor, Umeå University; Research Scholar, Trade Union Institute of Economic Research (FIEF); } \\
\text { Professor, Uppsala University. }\end{array}$ \\
\hline Erik Höök & $1948-62$ & $\begin{array}{l}\text { Head of Planning and Medium Term Surveys, Ministry of Finance; President, Jernkontoret (Swedish Steel Producers' } \\
\text { Association). }\end{array}$ \\
\hline Axel Iveroth & $1939-46$ & $\begin{array}{l}\text { Editor-in-Chief, Industria; Intelligence Officer, Swedish Embassy, Washington D.C.; Vice President, Cementa; } \\
\text { President, Federation of Swedish Industries. Co-founder of the Center for Business and Policy Studies (SNS). }\end{array}$ \\
\hline Ulf Jakobsson & $\begin{array}{l}1970-76,1994- \\
2005\end{array}$ & $\begin{array}{l}\text { Head of Planning and Medium Term Surveys, Ministry of Finance; Chief Economist, Confederation of Swedish } \\
\text { Enterprise (SAF); Handelsbanken; Federation of Swedish Industries. }\end{array}$ \\
\hline Anders Klevmarken & $1968-76$ & Professor, Gothenburg University (Statistics and Econometrics); Professor of Econometrics at Uppsala University. \\
\hline Lars Lidén & $1957-61$ & Federation of Swedish Industries, 1961-64. Subsequent career at Esselte (a multinational office supplies \\
\hline
\end{tabular}


Assar Lindbeck

Lars Lundberg

Curt Nicolin

Göran Normann

Åke Ortmark

Bengt Rydén

John Skår

Åke Sundström

Ingvar Svennilson

Birgitta Swedenborg

Jan Södersten

Hans B. Thorelli

Gunnar Törnqvist

Jan Wallander

Marcus Wallenberg

Lars Wohlin

Bengt-Christer

Ysander manufacturer), where he was deputy CEO until 1991.

1962-63, 1966-68, Professor, Stockholm School of Economics; Professor, Stockholm University; Director, Institute of International 1995- Economic Studies (IIES).

1969-72, 1989-91 Lecturer and Associate Professor, Umeå University; Research Scholar, Trade Union Institute of Economic Research; Professor, Örebro University.

Chairman 1985-93 President and subsequently Chairman of Asea/ABB; Chairman, Confederation of Swedish Enterprise (SAF).

1972-81 Research Manager, Federation of Swedish Industries; Principal Administrator, Public Management Service; Head of the Fiscal Affairs Division, OECD, Paris.

Economic commentator and journalist, Swedish Radio and the Swedish public service television company (SVT); Editor-in-Chief, Veckans Affärer; Writer, senior journalist, TV8, Axess-TV etc. Arguably the most renowned TV journalist in Sweden with a career in television spanning more than 50 years.

Editor-in-Chief, Veckans Affärer; President, Center for Business and Policy Studies (SNS); President, Stockholm Stock Exchange.

Lecturer, Stockholm University; Professor and Dean, Bodö Business School; Professor and Head of Center for Medical Innovations at Karolinska Institute, Solna. Co-founder, Stockholm School of Entrepreneurship (SSES).

1959-63, 1967-68

1941-49

Key positions in the Ministries of Finance and Industry.

Professor, Stockholm University; Director, Institute of International Economic Studies (IIES). Pioneered medium term surveys in the Ministry of Finance; author of Growth and Stagnation in the European Economy, a monumental study of European economic development in the interwar period commissioned by the United Nations European Commission for Europe.

1969-81, 1986-90 Expert Group on Public Finance (ESO), the Ministry of Finance; Economist, PK-Banken; Vice President, Center for Business and Policy Studies (SNS).

Professor and Dean of Faculty of Social Sciences, Uppsala University.

President, Center for Business and Policy Studies (SNS). Marketing Services Research, General Electric, New York; Professor of Management, University of Chicago and Indiana University.

Professor of Economic Geography, Lund Unversity.

Research Director and President, Center for Business and Policy Studies (SNS), 1950-53; President,

Sundsvallsbanken and Handelsbanken; Chairman, Handelsbanken. Writer of numerous books on management

Leading sponsor of economic research through the Jan Wallander and Tom Hedelius Foundation.

$1945-49$, CEO

1953-61

President and subsequently Chairman, Stockholms Enskilda Bank; Head of the Wallenberg sphere from 1946 until his death. The most powerful representative of Swedish industry in the postwar period.

75, Honorary

Chairman 1975-82

1960-72, CEO

$1973-1976$

1978-87

Chief Economist, Confederation of Swedish Enterprise (SAF), 1973-76; Undersecretary, Ministry of Finance;

Governor of the Swedish Central Bank; President, Stadshypotek; and European Union Parliamentarian.

Professor, Uppsala University.

Note: The field of professorships is only indicated if it is not Economics. Information about a person mentioned in the main text is not repeated. 